\title{
THE ANTI-ALLERGIC AND ANTIHISTAMINIC PROPERTIES OF HYDROBROMIDE 2-[4-(4'-CHLOROPHENYL)-2- PHENYLIMINOTHIAZOL-3-YL]-ETHANOL
}

\author{
O.Yu.Koshova, H.O.Ieryomina, L.O.Perekhoda, Z.G.Yeryomina \\ National University of Pharmacy
}

Key words: anti-allergic action; antihistaminic properties; hydrobromide 2-[4-(41- chlorophenyl)-2phenyliminothiazol-3-yl]-ethanol

\begin{abstract}
The study of the anti-allergic action of hydrobromide 2-[4-(41-chlorophenyl)-2-phenyliminothiazol$3-y l]$-ethanol under the code of 6.6 has been conducted. On the model of anaphylactic shock in guinea pigs it has been found that in the prophylactic administration in the dose of $5 \mathrm{mg} / \mathrm{kg}$ the test compound exhibits the anti-allergic activity at the level of the reference medicine "Claritin" tablets in the dose of $1 \mathrm{mg} / \mathrm{kg}-65 \%$ and $76 \%$, respectively. In "Ophthalmic response to introduction of histamine" test the compound studied showed the efficacy on average at the level of $72 \%$, and the reference medicine $83 \%$. The data obtained allow assuming that the marked antihistaminic properties play an important role in the mechanism of the anti-allergic action of compound 6.6. The research conducted prove the reasonability of further pharmacological study of hydrobromide 2-[4-(41- chlorophenyl)-2-phenyliminothiazol-3-yl]-ethanol with the aim of creating an effective anti-allergic medicine.
\end{abstract}

Taking into account the fact that the incidence of allergic, autoimmune, immunodeficiency diseases increases both in Ukraine and around the world the search for new anti-allergic medicines is an important task of modern experimental pharmacology [6]. In our previous works $[5,14]$ the synthesis of a new series of 2-[4-aryl(adamantyl)-2-phenyliminothiazol-3-yl]-ethanol derivatives was presented, and the virtual screening of the pharmacological activity, bioavailability and toxicity of the compounds synthesized was described. As a result of the studies conducted in silico it has been determined that these compounds have a high probability of the anti-allergic properties: as anaphylatoxin receptor antagonists (81\%) and antipruritic substances $(53 \%)$, for the treatment of allergic rhinitis (51\%) and other allergic diseases (50\%). In addition, they have favourable parameters of bioavailability and low toxicity $[5,14]$. Therefore, the expedience of the experimental pharmacological studies of the anti-allergic action of compounds of this group has been theoretically proven.

According to the results of the pharmacological screening concerning the antihistaminic activity among derivatives of 2-[4-aryl(adamantyl)-2-phenyliminothiazol3 -yl]-ethanol the most promising compound - hydrobromide 2-[4-(41- chlorophenyl)-2-phenyliminothiazol3 -yl]-ethanol under the code of 6.6 was selected. The synthesis of compound 6.6 was carried out by Hantzsch reaction [14].

The aim of the study was to determine the anti-allergic action and antihistaminic properties of a new original compound - hydrobromide $2-\left[4-\left(4^{1}\right.\right.$ - chlorophenyl)2-phenyliminothiazol-3-yl]-ethanol.

\section{Materials and Methods}

The experiments were conducted in guinea pigs weighing 350-450 g. During the experiment the animals were kept in the vivarium at a temperature of $18-24^{\circ} \mathrm{C}$, with the humidity of 50-60\%, the natural "day-night" light mode, in plastic cages, under standard conditions on a normal diet according to the current specifications. The experiment was carried out in compliance with the requirements of the European Convention "On protection of vertebrate animals used for experimental and other scientific purposes" (Strasbourg, 1986) [9].

Anaphylactic shock (AS) was reproduced by introduction of $1 \%$ egg white in the dose of $1 \mathrm{ml} / \mathrm{kg}$. Sensibilization of animals was performed three times a day according to the following scheme: the first injection subcutaneously, two subsequent injections - intramuscularly [2]. Hydrobromide 2-[4-(41-chlorophenyl)-2-phenyliminothiazol-3-yl]-ethanol was introduced orally in the dose of $5 \mathrm{mg} / \mathrm{kg}$ simultaneously with the protein injections and during the whole period of sensibilization (14 days). As a reference medicine (RM) "Claritin" tablets in the dose of $1 \mathrm{mg} / \mathrm{kg}$ introduced orally in a similar mode were used. Water was given to the animals from the positive control group.

On day 14 the animals of all experimental groups were introduced the final dose of the allergen ( $1 \%$ egg white solution in the dose of $1 \mathrm{ml} / \mathrm{kg}$ ) intraperitoneally. The severity of AS was assessed by the rating scale: 0 points - no reaction; 1 point - mild shock. Animals were anxious, feeble with a mild dyspnea. The symptoms disappeared in 20-30 min; 2 points - moderate shock. Small convulsions, severe bronchospasm. The symptoms disappeared in 1-2 h; 3 points - severe shock. General convulsions, asphyxia, the animal falls on its side, but does not die; 4 points - lethal shock.

The antihistaminic action of hydrobromide 2-[4-(41chlorophenyl)-2-phenyliminothiazol-3-yl]-ethanol was studied in "Ophthalmic response to introduction of histamine" test. The experiments were conducted in 18 light-coloured guinea pigs weighing 350-450 g. Com- 
pound 6.6 was given orally as a single dose of $5 \mathrm{mg} / \mathrm{kg}$ $40 \mathrm{~min}$ before testing. As a reference medicine "Claritin" tablets in the dose of $1 \mathrm{mg} / \mathrm{kg}$ introduced in a similar mode were used. Water was given to the animals from the positive control group.

Animals of the positive control group were taken distilled water in the amount equivalent to the body weight. In 40 min after introduction of the substances studied to guinea pigs one drop of $1 \%$ aqueous solution of histamine hydrochloride (manufactured by "Fluka", Switzerland) was instilled in one eye. The second eye served as a control. The severity of the ophthalmic response was assessed in 10-15 min after histamine introduction according to the three-point rating scale [3]: 0 points the absence of the visible reaction; 1 point - mild reaction (negligible edema of the eyelids, brief scratching of the eye, little lacrimation); 2 points - moderate reaction (moderate edema of the eyelids and the conjunctiva, mild hyperemia of the conjunctiva and the sclera, moderate lacrimation, brief scratching of the eye); 3 points - severe reaction (severe edema of the conjunctiva and the sclera, severe hyperemia of the conjunctiva and the sclera, increased lacrimation, distinct frequent scratching of the eye).

The antihistaminic activity of the compound studied was determined by its ability to reduce the severity of the ophthalmic response compared to the positive control and expressed in percentage by the formula:

$$
\mathrm{AH}=\left(\mathrm{OR}_{\mathrm{C}}-\mathrm{OR}_{\mathrm{EX}}\right) / \mathrm{OR}_{\mathrm{C}} \times 100 \%,
$$

where: $\mathrm{AH}-$ is the antihistaminic activity, $\% ; \mathrm{OR}_{\mathrm{C}}-$ is the severity of the ophthalmic response in the group of animals of the positive control, in points; $\mathrm{OR}_{\mathrm{EX}}-$ is the severity of the ophthalmic response in the groups of experimental animals, in points.

The data obtained were expressed using the arithmetic mean and the minimum and maximum values of variation series. The statistical analysis was performed using non-parametric Kruskal-Wallis test and Wilcoxon-MannWhitney test. Differences between the control and experimental groups were considered to be statistically significant at $\mathrm{p}<0.05$. The experimental data were processed using such statistical software as "Statistica, v. 6.0" and "Excel, 2007" [8,12].

\section{Results and Discussion}

Allergic reactions of the immediate type (IgE-mediated) play a key role in the pathogenesis of anaphylactic shock, bronchial asthma, Quincke's edema and allergic dermatosis - urticaria $[1,7,10]$. These reactions occur by formation of the antigen-antibody immune complexes on the surface of mast cells and basophils. As a result of interaction of these complexes with the membrane receptors, in which IgE molecules are fixed, the release of a number of biologically active substances (histamine, serotonin, prostaglandins, eosinophil chemotactic factor of anaphylaxis, platelet-activating factor, etc.), which cause general and local action on tissues, from the mast cells takes place $[1,7,10]$. In the experiment it leads to the spasm of smooth muscles of the bronchi of the medium
Table

Determination of the anti-allergic activity of hydrobromide 2-[4-( $4^{1}$-chlorophenyl)-2phenyliminothiazol-3-yl]-ethanol (compound 6.6) in

"Anaphylactic shock" test in guinea pigs $(\mathrm{n}=6)$

\begin{tabular}{|l|c|c|c|}
\hline Groups of animals & $\begin{array}{c}\text { Dose, } \\
\mathrm{mg} / \mathrm{kg}\end{array}$ & $\begin{array}{c}\text { The severity } \\
\text { of AS, points } \\
M(\min ; \max )\end{array}$ & $\begin{array}{c}\text { The anti- } \\
\text { allergic } \\
\text { activity, \% }\end{array}$ \\
\hline Positive control & - & $2.3(1 ; 3)$ & - \\
\hline Compound 6.6 & 5.0 & $0.8(0 ; 2)^{*}$ & $65 \%$ \\
\hline "Claritin" tablets & 1.0 & $0.5(0 ; 2)^{*}$ & $78 \%$ \\
\hline
\end{tabular}

Note: ${ }^{*}$ - statistically significant differences in relation to the positive control, $\mathrm{p}<0.05$.

and small size accompanied by asphyxial convulsions, cyanotic ear and nose.

In 8-10 min after introduction of the anaphylaxisprovoking dose of protein to guinea pigs from the positive control group the prodromal phenomena of anaphylactic shock (pronounced anxiety, intense scratching of the snout, rumpleness of the hair coat) were observed. Prior 30 min AS was developed in these animals, it manifested by convulsions, the lateral position of the animals, and asphyxia. In animals of this group the degree of AS severity was assessed in 1-3 points (Table). The clinical manifestations of AS described for all the animals that remained alive disappeared in 60 min after introduction of the anaphylaxis-provoking dose. During the first six hours of observation after introduction of the antigen anaphylaxis-provoking dose all animals were active, their respiratory rate and appearance corresponded to physiological norms. During the day and the following days after introduction of the anaphylaxis-provoking dose all animals remained alive.

The prophylactic administration of compound 6.6 under study significantly reduced the severity of the anaphylactic reaction, which was assessed from 0 to 2 points in animals of this group (Table). The anti-shock activity of compound 6.6 was $65 \%$. The reference medicine "Claritin" tablets revealed more marked activity - 78\%; however, statistical differences between experimental groups were not recorded (Tab.). It indicates the same anti-allergic activity of the substances studied by the severity.

In the external manifestations of allergic reactions histamine, which allergic effects are mediated via $\mathrm{H}_{1}$-receptors, plays a special role $[4,11]$. The release of histamine from mast cells along with other biologically active substances after repeated exposure of antigen with sensitized cells leads to the spasm of smooth muscles in the bronchi and intestines, increase the mucus secretion in the bronchi and nasal cavity, chemosis of eosinophils, neutrophils and formation of prostaglandins, increase the suppressive action of T-lymphocytes. The effect of histamine on the blood vessels is manifested by constriction of the large blood vessels and dilation of small ves sels, increased capillary permeability; as a result, the edema of the respiratory mucosa, skin hyperemia and pressure drop developed $[10,11]$. When developing allergic reactions the level of histamine increases in the blood 


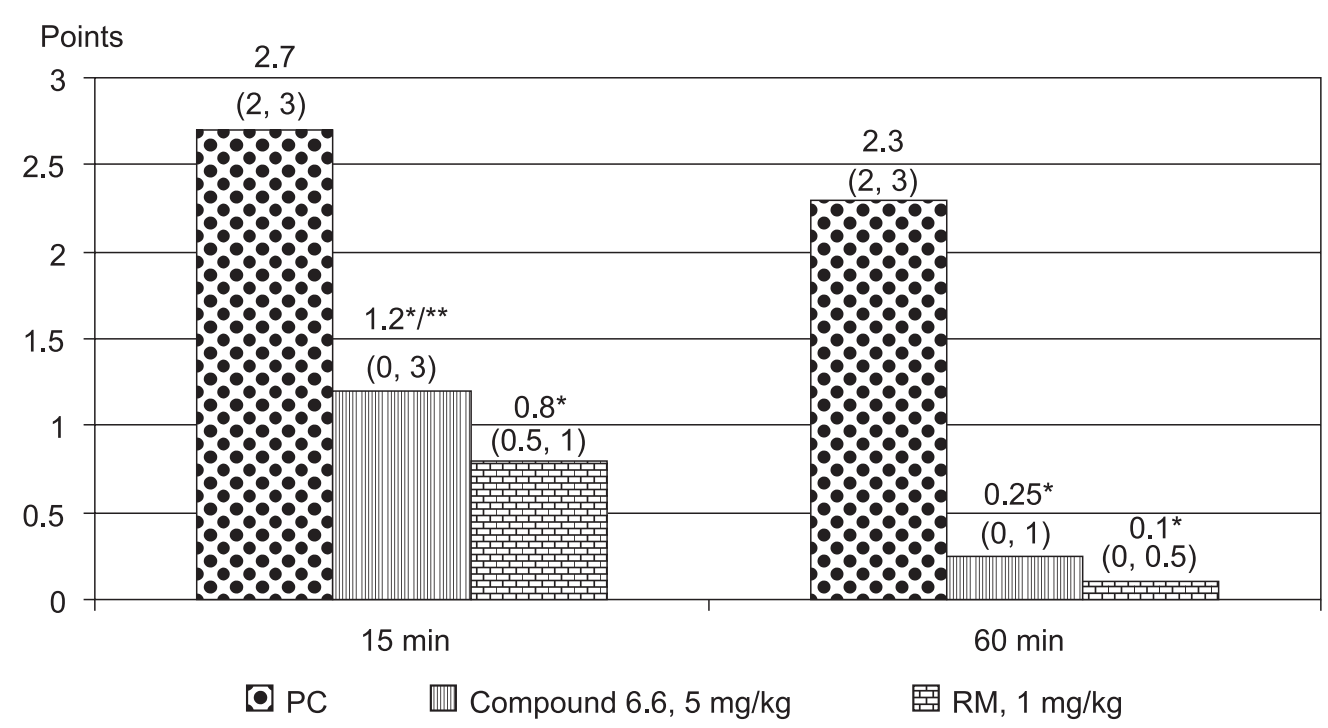

Fig. Determination of the antihistaminic action of compound 6.6 under the conditions of "Ophthalmic response to introduction of histamine" test. Notes: ${ }^{*}$ - statistically significant differences in relation to the positive control, $\mathrm{p}<0.05 ; \mathrm{PC}$ - positive control; $\mathrm{RM}$ - reference medicine "Claritin" tablets in the dose of $1 \mathrm{mg} / \mathrm{kg}$.

and tissues, therefore, antihistamines are used in the treatment of most allergic diseases [13].

Taking into account the above the task of the next phase of our study was to determine the antihistaminic properties of compound 6.6 in "Ophthalmic response to introduction of histamine" test. According to the studies conducted in guinea pigs of the positive control group the instillation of histamine in the eye led to development of chemosis: the severe edema of the conjunctiva and the eyelids was observed. Already in 10-15 min the reaction intensified - the edema was accompanied by increased lacrimation, hyperemia of the conjunctiva and the eyelids. The maximum development of the inflammatory reaction of the eye was observed in $15 \mathrm{~min}$ after introduction of histamine. The severity of the response was assessed in 2-3 points (Fig.).

The prophylactic administration of compound 6.6 and RM "Claritin" tablets significantly prevented development of chemosis. The severity of the animals' response to histamine was significantly lower compared to the animals of the positive control (Fig.). On average the antihistaminic activity of compound 6.6 was at the level of $72 \%$, and $\mathrm{RM}-83 \%$.
Therefore, by the severity of the antihistaminic action of hydrobromide 2-[4-(4'-chlorophenyl)-2-phenyliminothiazol-3-yl]-ethanol was not inferior to the reference medicine - the classic blocker of $\mathrm{H}_{1}$-histamine receptors.

\section{CONCLUSIONS}

On the model of anaphylactic shock hydrobromide 2-[4-(4'-chlorophenyl)-2-phenyliminothiazol-3-yl]-ethanol in the dose of $5 \mathrm{mg} / \mathrm{kg}$ exhibits the anti-allergic activity in the prophylactic administration; by its intensity it is not inferior to the reference medicine. On the model of "Ophthalmic response to introduction of histamine" test the prophylactic administration of hydrobromide 2-[4-(4'-chlorophenyl)-2-phenyliminothiazol-3-yl]-ethanol prevents development of chemosis, swollen mucosa of the eye in guinea pigs, and it allows suggesting the presence of the blocking action in the compound studied in relation to $\mathrm{H}_{1}$-histamine receptors. The data of the pharmacological research prove the reasonability of further study of the pharmacological properties of hydrobromide 2-[4-(4'-chlorophenyl)-2-phenyliminothiazol-3-yl]-ethanol with the aim of elucidation of the mechanisms of the anti-allergic action of this compound to create an effective anti-allergic medicine for treating allergic diseases.

\section{REFERENCES}

1. Адо А.Д. Общая аллергология. - М.: Медищина, 1978. - С. 361-364.

2. Бутенко Г.М., Терешина О.П., Максимов Ю.М. та ін. Доклінічне вивчення сенсибілізуючої дії лікарських засобів: Метод. рекоменд. - К., 2002. - С. 5-27.

3. Воспроизведение заболеваний у животных для экспериментально-терапевтических исследований // Под ред. Н.В.Лазарева. - Л.: Медгиз. Ленинградское отделение, 1954. - С. 26-48.

4. Дранник Г.Н. Клиническая иммунология и аллергология. - Одесса: АстроПринт, 1999. - 392 с.

5. Еремина А.А., Еремина 3.Г., Сыч И.А. и др. // Тези доп. всеукр. наук.-практ. конф. молодих учених та студ. за міжнар. участю, присвячена дню науки: «Сучасні аспекти медицини і фармації-2016» (12-13 травня 2016 р.). - Запоріжжя, 2016. - С. 231.

6. Канівець С. // Клінічна імунол. Алергол. Інфектол. - 2014. - №5 (74). - С. 17-27.

7. Клиническая иммунология и аллергология / Под ред. Л.Йегера. - М.: Медицина, 1986. - Т. 1. - 476 с.; T. 2. -512 c.; T. 3. -448 c. 
8. Лапач С.Н., Чубенко А.В., Бабич П.Н. Статистические методы в медико-биологических исследованиях с использованием Excel. - К.: Моріон, 2001. - 320 с.

9. Надлезсащая производственная практика лекарственных средств / Под ред. Н.А.Ляпунова, В.А.Загория, В.П. Георгиевского, Е.П. Безуглой. - К.: Морион, 1999. - С. 508-545.

10. Пыикий В.И., Адрианова Н.В., Артомасова А.В. Аллергические заболевания. - М.: Триада-Х, 1999. - 470 c.

11. Регеда М.С., Кресюн В.Й., Федорів Я.М. Клінічна алергологія. - Львів: Сполом, 2004. - 209 с.

12. Халафян А.A. STATISTICA 6. Статистический анализ данных. 3-е изд.: Учебник. - М.: ООО «БиномПресс», 2007. -512 c.

13. Gonzalo M.A., Moneo I., Ventas P. et al. // Allergy. - 1997. - Vol. 52, Iss. 5. - P. 598-599.

14. Yeromina H.O., Drapak I.V., Perekhoda L.O. et al. // Der Pharma Chemica. - 2016. - Vol. 8, Iss. 3. - P. 64-70.

\section{ПРОТИАЛЕРГІЧНІ ТА АНТИГІСТАМІННІ ВЛАСТИВОСТІ ГІДРОБРОМІДУ 2-[4-(4'-ХЛОРОФЕНІЛ)-2-ФЕНІЛІМІНОТІАЗОЛ-3-ІЛ]-ЕТАНОЛУ \\ О.Ю.Кошова, Г.О.Єрьоміна, Л.О.Перехода, З.Г.Єрьоміна}

Ключові слова: похідні 1,3-тіазолу; протиалергічна та антигістамінна активність Проведено дослідження антиалергічної дії та антигістамінних властивостей гідроброміду 2-[4-(41-хлорофреніл)-2-френілімінотіазол-3-іл]-етанолу. На моделі анафрілактичного шоку у морських свинок встановлено, що за профрілактичного введення у дозі 5 мг/ка досліджувана сполука виявляє антиалергічну активність на рівні препарату порівняння таблеток «Кларитин» у дозі 1 ме/ке 65\% та 76\%, відповідно. У тесті «Офртальмореакція на введення гістаміну» гідробромід 2-[4-(41-хлорофреніл)-2-френілімінотіазол-3-іл]-етанолу виявив ефективність у середньому на рівні 72\%, препарат порівняння - 83\%. Отримані дані дозволяють припустити, що в механізмі антиалергічної дії досліджуваної сполуки важливу роль відіграють виразні антигістамінні властивості. Проведені дослідження обгрунтовують доцільність подальшого фрармакологічного вивчення гідроброміду 2-[4-(41-хлорофреніл)-2-френілімінотіазол3-іл]-етанолу з метою створення ефрективного протиалергічного засобу.

\section{ПРОТИВОАЛЛЕРГИЧЕСКИЕ И АНТИГИСТАМИННЫЕ СВОЙСТВА ГИДРОБРОМИДА 2-[4-(4'-ХЛОРФЕНИЛ)-2-ФЕНИЛИМИНОТИАЗОЛ-3-ИЛ]-ЭТАНОЛА \\ Е.Ю.Кошевая, А.А.Еремина, Л.А.Перехода, З.Г.Еремина}

Ключевые слова: производные 1,3-тиазола; противоаллергическая и антигистаминная активность

Проведено исследование противоаллергического действия и антигистаминных свойств гидробромида 2-[4-(41-хлорофренил)-2-френилиминотиазол-3-ил]-этанола. На модели анафилактического шока у морских свинок установлено, что при профрилактическом введении в дозе 5 мг/ка исследуемое соединение проявляет антиаллергическую активность на уровне препарата сравнения таблеток «Кларитин» в дозе 1 мг/ка 65\% и 76\%, соответственно. В тесте "Офртальмореакция на введение гистамина» гидробромид 2-[4-(41-хлорофенил)2-френилиминотиазол-3-ил]-этанола проявил эффрективность в среднем на уровне $72 \%$, препарат сравнения - 83\%. Полученные данные позволяют предположить, что в механизме антиаллергического действия исследуемого соединения важную роль играют отчетливые антигистаминные свойства. Проведенные исследования обосновывают целесообразность дальнейшего фрармакологического изучения гидробромида 2-[4-(41-хлорофренил)-2френилиминотиазол-3-ил]-этанола с целью создания эфрфективного противоаллергического средства. 